\title{
Anishinaabe Adaptation to Environmental Change in Northwestern Ontario: a Case Study in Knowledge Coproduction for Nontimber Forest Products
}

\author{
$\underline{\text { Iain J. Davidson-Hunt }}^{1}, \underline{\text { C. Julián Idrobo }}^{1}, \underline{\text { Ryan D. Pengelly }}^{2}$ and $\underline{\text { Olivia Sylvester }}^{1}$
}

\begin{abstract}
Interaction, negotiation, and sharing knowledge are at the heart of indigenous response to global environmental change. We consider Anishinaabe efforts to devise new institutional arrangements in response to the process of colonialism and changing global markets. Our findings are based on collaborative research undertaken with Anishinaabe colleagues from Pikangikum First Nation, northwestern Ontario. We worked with elders to understand their knowledge, preferences, and opinions regarding appropriate institutional arrangements for the co-production of knowledge required to develop nontimber forest products. We began our research by asking about the values, institutions, and conditions that guide plant harvesting, and then the conditions necessary to coproduce new knowledge regarding plant products with external partners. Results were discussed during focus groups and community meetings, and were modified based on that feedback. This research resulted in a framework based on the values, institutions, and conditions that are necessary for the coproduction of new knowledge. In this framework, Pikangikum people - through Anishinaabe teachings and collaborative partnerships-guide knowledge coproduction through meaningful participation as research advisors in the development of knowledge, institutions, and technologies. Coproducing knowledge in response to environmental change requires new institutional arrangements that provide community control, meaningful collaboration and partnerships, and significant benefit sharing with Pikangikum people.
\end{abstract}

Key Words: Anishinaabe; boreal forest; Canada; coproduction of knowledge; global environmental change

\section{INTRODUCTION}

We focus on the role of custom, values, and previous institutions in shaping new institutional arrangements for knowledge coproduction. We do this through a case study from the boreal forest of Canada in which Anishinaabe ${ }^{[1]}$ elders considered appropriate institutional arrangements for the coproduction of knowledge for plant products in the face of environmental change (Pengelly 2011, Pengelly and Davidson-Hunt 2012). Coproduction of knowledge can be understood as the "process of bringing a plurality of knowledge sources and types together to address a defined problem and build an integrated or systems-oriented understanding of that problem" (Armitage et al. 2011:996).

We bring the concept of coproduction of knowledge to the focus of this Special Issue on traditional ecological knowledge (TEK), resilience, and global environmental change for three main reasons. First, in Canada, Aboriginal people of the subArctic bring TEK into their emerging relations with state governments (Houde 2007). Adaptation to environmental change will not occur in isolation but through complex interactions among knowledge systems (Berkes 2008). Second, the resilience of Aboriginal societies over the past 500 years has occurred in the context of colonial relations and global natural resource markets. Adapting to change has involved both resisting colonial processes of acculturation and incorporating knowledge, practices, and technologies consistent with First Nation customs and values (Turner et al.
2003, Miller et al. 2010, Davidson-Hunt and Turner 2012). Third, given this colonial history, First Nations in Canada have insisted that TEK is not something to be used by others but rather what they bring to the process of producing knowledge in response to challenges like environmental change (Davidson-Hunt and O'Flaherty 2007).

In an Anishinaabe perspective, as well as in much current literature, environment is the full set of ecological, social, cultural, political, and technological relations within which an individual is embedded (Ingold 2000, Davidson-Hunt and Berkes 2003, Latour 2005). Adaptation, in this perspective, can be in response to changes in any one of these domains (Davidson-Hunt 2006, Ellen 2007). We highlight Anishinaabe responses to political and economic changes, and the institutional arrangements they are devising, in an effort to broaden the discussion of global environmental change, which tends to emphasize biophysical and climatic drivers of change. As noted in the Introduction to this Special Issue, the emergence of new institutional arrangements for the management of natural resources is critical in the face of global environmental change - a perspective also reflected in recent work on social-ecological resilience (Berkes et al. 2003). We consider one such case in which an Anishinaabe community has been building the capacity to respond to change through the development of new institutional arrangements for the coproduction of knowledge. 
Fig. 1. Location of Pikangikum First Nation.

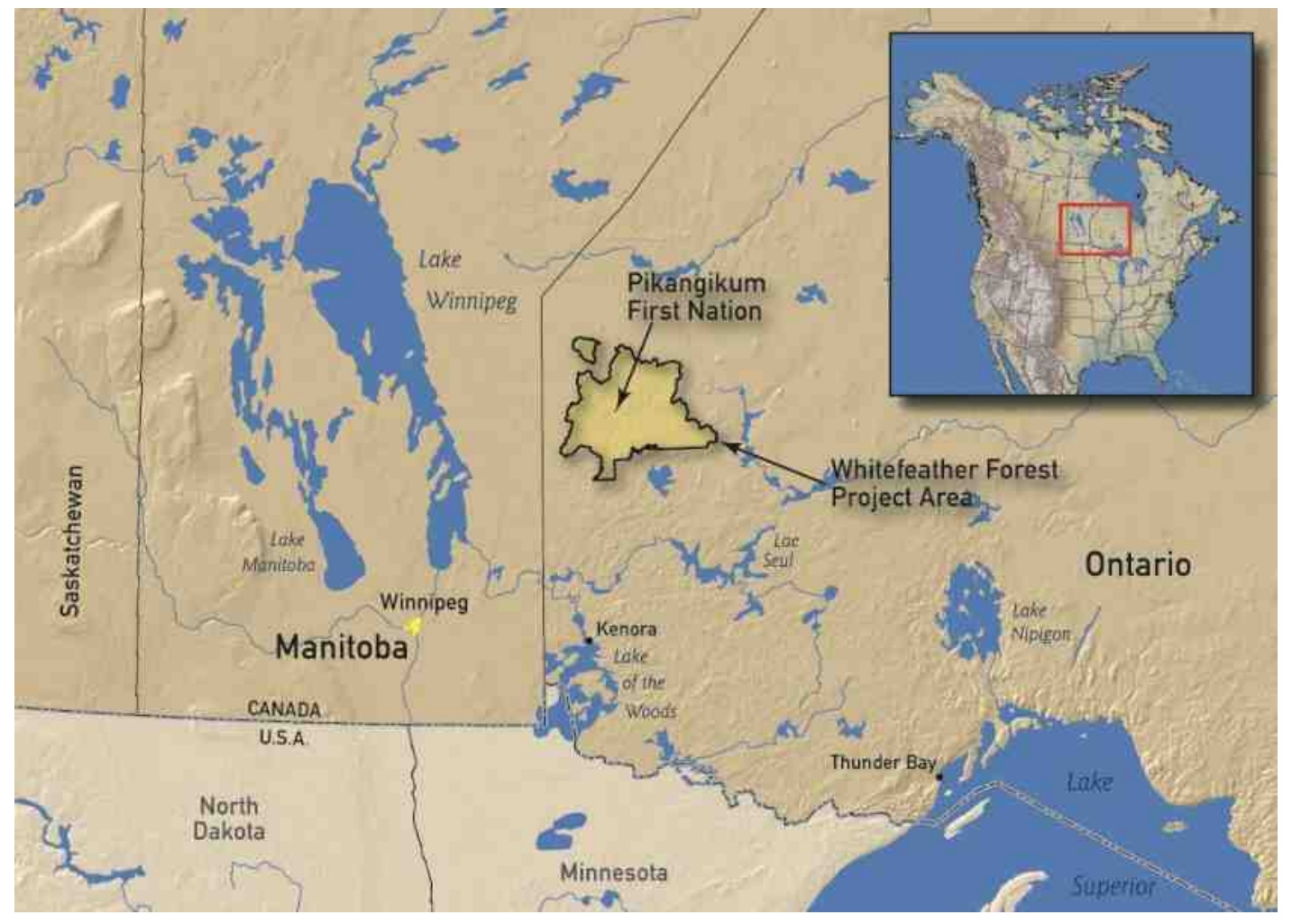

\section{METHODOLOGY}

\section{Case study}

\section{Pikangikum First Nation}

Pikangikum First Nation (PFN) is an Anishinaabe (Ojibway) community of approximately 2400 people in a geographically isolated area of northwestern Ontario, Canada (Fig. 1). Subsistence practice has changed and commercial land-based activities have declined since the downturn of fur markets in the 1970s (Berkes and Davidson-Hunt 2009, Deutsch and Davidson-Hunt 2010). Nonetheless, hunting, trapping, and fishing activities are still a fundamental part of many community members' way of life and Pikangikum's mixed economy. The customary use of plants as medicine, food, technologies, and domestic necessities continues, but it has understandably diminished with the emergence of provincial health care, the establishment of the local nursing station, and the ready availability of foods at the Northern Store.

At present, government welfare and local jobs with the Band make up the largest sources of income for individual band members (Mamow Sha-way-gi-kay-win 2009). The serious lack of jobs and market opportunities in Pikangikum, the encroaching forestry and mining exploration from the south, and the desire of many members to remain in the community and live close to family and the local environment rather than emigrate to find jobs off-reserve have fueled the community's strong desire for economic revival through the Whitefeather Forest Initiative (WFI).

\section{Whitefeather Forest Initiative}

The WFI is a community economic renewal and resource stewardship initiative of the PFN that is related to the management of 1.3 million hectares of boreal forest. These lands are provincial Crown lands that surround the reserve lands, and through an agreement with the Province of Ontario were designated as the Whitefeather Forest Planning Area (WFPA). The WFPA brought together the contiguous traplines for which Pikangikum band members were trapline license holders and makes up a portion of the lands Pikangikum identifies as their traditional territory. The WFI seeks to develop economic opportunities while maintaining its "ancestral stewardship responsibilities for Keeping the Land (Cheekahnahwaydahmunk Keetahkeemeenahn) for the continued survival and well-being of Pikangikum people" (PFN and OMNR 2006:1).

In the 1990s, the community formed the Whitefeather Forest Management Corporation (WFMC) as its main planning and development agency. Within this corporation, a Whitefeather 
Forest Elders Steering Group (WFESG) was designated to guide and supervise development of community-based enterprise, partnerships with relevant stakeholders, and other planning activities within the WFPA. In 2006, the PFN and the Ontario Ministry of Natural Resources (OMNR) signed a land use strategy, "Keeping the Land," that outlines the particular terms, vision, and intents of future economic activities in the Whitefeather Forest. This land use strategy reflects an unprecedented shift in First Nation-provincial government relations in Ontario from a colonial to a more collaborative working relationship (Nikisher 2008). Pikangikum's land use strategy outlines various land uses and activities, including forestry, mining, ecotourism, customary activities, and nontimber forest products (NTFPs) (PFN and OMNR 2006). To date, lands have been identified for commercial forestry managed through a sustainable forest license held by the First Nation and designated protected areas to be managed in partnership with the Province of Ontario. We focus on the land use direction identified by the First Nation within the strategy for NTFPs. This land use occurs in both areas designated for commercial forestry and as protected areas.

In the strategy, NTFPs are referred to as Nahnahtookkaykoon Kahohcheeohsheecheekahtaykeemah Ahkeeng, which signify those things that grow from the land (e.g., biological resources such as plants, mosses, mushrooms), and for which commercial opportunities might be considered. These are distinguished from customary practices that are not commercial. This is an important distinction. The PFN, through the land use strategy, agreed to management regulations for commercial land uses, but subsistence harvests are undertaken according to custom. This is consistent with the PFN's understanding of their relationship to the Crown as established through treaties. The focus of NTFP land use directions is to find new commercial opportunities for biological resources in response to the collapse of commercial harvests of fur and fish in the 1980s (Nikisher 2008).

The land use strategy establishes new institutional arrangements to manage land in response to colonialism, and new commercial land use directions respond to a significant change in global markets. In support of this effort, the PFN established the Whitefeather Forest Research Cooperative agreement (WFRC 2004) between the PFN, the University of Manitoba, and several other universities. The goal of the WFRC is "to bring together a partnership of supports and participants in the development of the Whitefeather Forest Initiative in the form of a knowledge network where Pikangikum people are in the driver's seat regarding the research programme" (WFRC 2004:1). We explored how customs and values shape the emergence of new institutional arrangements for knowledge coproduction by conducting extended conversations with elders of the PFN.

\section{Data collection procedures}

\section{Research participants}

This research was conducted with active harvesters and elders within the WFMC and WFESG, and builds on 10 years of research undertaken in partnership with the First Nation. We introduced this research to community members during two meetings of the WFESG held in Pikangikum in the spring of 2009. The research purpose, objectives, methods, and fieldwork plan were presented and discussed in the first meeting. The revised research plan was discussed in the second meeting and was approved by the steering group. Fieldwork was conducted from June to October 2009. The meetings allowed us to identify community members who were interested in and knowledgeable about the topics of research. Our sampling strategy was both purposive in that we included those individuals who were knowledgeable about the topic (e. g., Bernard 2006, Tongco 2007), and was consistent with our ethics protocol that required us to include only those who volunteered to be involved in the research. In addition, information about the project was broadcast in Anishinaabe using the community radio station before each meeting. The meetings and a verification workshop included 25-35 community members as well as employees of the WFMC.

\section{Field trips, interviews, and workshops}

Ten field trips, which lasted from several hours to several days, provided an opportunity to discuss knowledge, values, and customary practices related to plant and other resource harvesting. In order to understand how plant knowledge was learned and produced, walking probes on the land with harvesters and elders were employed as part of unstructured interviews (De Leon and Cohen 2005). In total, we conducted 13 semistructured individual interviews with seven individuals (four male elders and three male leaders) to discuss knowledge, preferences, and opinions about coproducing knowledge to develop new economic uses of plants (two elders were interviewed multiple times).

Four group interviews were held, each of which included two to four individuals (total of six male and two female elders), to consider the degree of consensus and difference regarding the coproduction of knowledge for NTFPs. Our intention was to generate conversations about how customs and values related to customary harvest practices influence the production of knowledge for the design and commercialization of NTFPs. Our field trips and some of the individual interviews focused on customary harvesting, while the remaining individual and group interviews focused on NTFPs by employing an elicitation technique that uses objects such as photos and videos (Sayre 2006) or products in consumer choice research (Breivik and Supphellen 2003). Focusing on NTFPs allowed us to discuss the values that guide the process by which knowledge is generated, and the role of partnerships within such a process. 
Table 1. Anishinaabe knowledge and institutions related to the coproduction of knowledge.

\begin{tabular}{|c|c|c|c|}
\hline \multicolumn{2}{|c|}{ Anishinaabe knowledge } & \multicolumn{2}{|c|}{ Potential coproduction of knowledge } \\
\hline Theme & Anishinaabe teachings & Institutions of knowledge & Elders' perspectives \\
\hline Source of knowledge & $\begin{array}{l}\text { Anishinaabe knowledge and all things } \\
\text { on the land were a gift from the } \\
\text { Creator with the purpose of health and } \\
\text { well-being of the Anishinaabeg. } \\
\text { Anishinaabe knowledge is not owned } \\
\text { by anyone. }\end{array}$ & $\begin{array}{l}\text {-Respect } \\
\text {-Purpose } \\
\text {-Gifting/reciprocity with } \\
\text { other-than-human beings }\end{array}$ & $\begin{array}{l}\text { The land and its resources must be } \\
\text { respected and valued as gifts from the } \\
\text { Creator. The Creator gifted resources } \\
\text { with a specific purpose, and nontimber } \\
\text { forest product (NTFP) development } \\
\text { should maintain the original intention. } \\
\text { When harvesting mushkeekeeh, tobacco } \\
\text { must be gifted to ensure proper respect } \\
\text { and its efficacy. }\end{array}$ \\
\hline
\end{tabular}

Knowledge specialists

Knowledge access, sharing, and use

Knowledge attainment and innovation
Anishinaabe knowledge is maintained through Pikangikum elders' teachings about the correct use of Anishinaabe knowledge and products.

Common and special knowledge are shared or exchanged under different conditions. Edible food knowledge is the least confidential. Common medicinal knowledge is moderately confidential. Special medicinal knowledge is highly confidential.
-Guidance of knowledge specialists

-Elder guidance -Committed, long-term partnerships - Gifting/reciprocity with knowledge specialists
Knowledge specialists must guide all stages of NTFP planning, development, and commercialization.

Elders must be in the driver's seat regarding resource development. Through long-term partnerships, elders expect to engage in cross-cultural learning experiences and knowledgesharing exercises with scientists. When knowledge specialists provide knowledge of NTFPs, they must be compensated with goods or monetary payment to show respect for the knowledge and power of the product.

Through new institutions, elders seek to bring scientific and Anishinaabe knowledge together for product and knowledge coproduction and innovation, with the consent of Anishinaabe knowledge specialists.

\begin{abstract}
All Anishinaabe knowledge is obtained through elders' teachings and experience on the land. Special knowledge is acquired through Anishinaabe methods of personal experience on the land, apprenticeships, dreaming, fasting and relationships with other-than-human beings.
\end{abstract}

-Collaborative decision making and knowledge generation/innovation

\section{RESULTS}

Because the dominant language in Pikangikum is Auhneesheenuhbaymooweehn, an Algonquian language, Mr. Paddy Peters, land use coordinator of WFMC, translated for almost all the interviews and during all workshops, while three other community members translated for the remaining three interviews. Interview audio recordings were digitally stored and transcribed verbatim. Data were coded and analyzed using Textual Analysis Markup System (TAMS) software. Primary code groups included customary NTFPs, novel NTFPs, partnerships, and benefit sharing. Codes were iteratively subclassified throughout data analysis and resulted in themes that are discussed in the Results.

\section{Anishinaabe customary teachings and the production of knowledge}

In Table 1 we summarize Anishinaabe teachings that interweave ideas on the nature of knowledge (ontology), acceptable ways to construct knowledge (epistemology), and the resultant value attributed to knowledge (axiology). Such teachings are important in terms of what is seen as authoritative knowledge, and as such, relevant in terms of guiding behavior during periods of change (Davidson-Hunt 2006, DavidsonHunt and O'Flaherty 2007). We expand on the main teachings to explain how they are translated into institutions that can guide the coproduction of knowledge. We begin by discussing how knowledge about plants and their uses was produced 
customarily, and then we switch to discussing how "new" knowledge could be coproduced through partnerships with others.

\section{Sources of knowledge}

For the Anishinaabe, knowledge is more than information. In the act of creation, Pikangikum elders say, the Creator gifted the land, the resources, and Anishinaabe knowledge of the land for the survival and well-being of the Anishinaabeg. Elder Charlie Peters explains this idea, specifically in relation to plant medicines (mushkeekeeh): "The knowledge that our people had of our medicine was given to them by the Creator. Keepee eesheemeeneekooweehseeh, or they have that gift and the knowledge of those plants, is a term used if a certain person has a certain gift, whatever that may be" (interview, Aug. 12, 2009).

In this passage, elder Charlie Peters alluded to another element of Anishinaabe knowledge, namely the skill, knowledge, or particular gift an individual gains at a particular moment through their personal experience.

The Anishinaabeg obtain specific knowledge through individual gifts or skills, but they also cultivate it through personal experience on the land and interactions with knowledge specialists. Pikangikum elders are the community's experts, advisors, and traditional authority. As the late-elder Norman Quill (interview, Oct. 4, 2009) explained "...the auhkeewaysee was the older man that possessed the knowledge of medicine and prescribed that medicine. Keekeekaycheekahtayneeh means that the people learned from or observed [the older man] who taught the knowledge."

Elders also taught how to learn from other-than-human beings. Elder Matthew Strang explained that "when you go and do this ten-day fast, you will begin to have dreams. You will begin to dream about someone coming to you and speaking to you, coming to reveal and talk to you (interview, Aug. 19, 2009)." These beings have been considered "supernatural" or "spiritual" beings, but Hallowell (1992:64) describes otherthan-human beings as a more appropriate label to refer to "animate beings to whom the Ojibway [Anishinaabeg] attribute essentially the same characteristics as themselves," but "have more power at their disposal than human beings, and this is why the humans need the help of other than human persons."

Although the ultimate source of Anishinaabe knowledge is the Creator, individuals adapt elders' teachings and cultivate knowledge through personal experience on the land. Thus, Anishinaabe knowledge is contingent upon the life experience of each individual. Each person knows what he or she has been taught by his or her elders and what they have learned themselves through the time they have spent on the land. Lateelder Norman Quill commented that his knowledge is not "all" knowledge but that which he had learned from his elders over his lifetime (meeting, May 29, 2009).

\section{Common and specialized knowledge}

While most elders of the community share a large degree of knowledge, certain individuals hold other specific or special knowledge. Common knowledge refers to knowledge, practices, and skills that are freely shared and widely known within Pikangikum and/or in other Anishinaabe communities of the boreal forest. Much of this knowledge is shared through conversations in the community (via telephone, two-way radios, or during leisure time), when harvesting plants, hunting, and fishing on the land, or when undertaking other land-based pursuits. It can also be shared through the telling of stories when journeying on the land. On the other hand, specialized knowledge, along with its associated practices and skills, is learned through specific training over an extended period of time. Therefore, within the domain of plant medicines, there is both common knowledge that is widely shared and specialized knowledge that only knowledgeable individuals possess.

According to the late-elder Oliver Hill, special knowledge and experience existed at a "higher level," and was often held by skilled medicine men or women and was associated with ceremonial healing, such as the Wabano (meeting, Jan. 9, 2009). This "higher level" medicinal knowledge entailed more complex recipes, combinations of ingredients, and specific remedies for a variety of illnesses. Elders, such as the lateelder Norman Quill, Matthew Strang, Oliver Hill, Alex Suggashie, Solomon Turtle, and Sam Quill, mentioned that only gifted individuals had special knowledge that was cultivated through apprenticeships, special training from a young age, and traditional methods of knowledge innovation, such as personal experiences, fasting, dreaming, and/or relationships with other-than-human beings. When dreaming and fasting were involved, other-than-human beings, or the Creator, may have revealed new knowledge during specific cultural practices.

Older individuals could also fast and dream for specific purposes, if this was the individual's practice. While many individuals would be taught to pay attention to the environment in relation to harvesting plants, animals, and fish for food, there were also other people who would have been taught to pay particular attention to other domains of environmental knowledge. While all people had the potential to produce new knowledge, there were individuals trained by elders to do so; these individuals were recognized as more authoritative in producing new knowledge.

When sharing or providing medicines, there were also specific Anishinaabe procedures for obtaining those products, which equally applied to the knowledge itself. 
"Our people followed these processes that were taught. We were given these as instructions. For instance, you have to harvest medicine from a clean area. After you were done using the medicine you would return it to a clean area. This was the instruction. They respected these teachings. Kuhkeenuh kaykoon, or everything that you see, is what our people were given. And not everyone had this knowledge. It was only some who were gifted to give medicine away or to distribute medicine. You had to be gifted to do that. You had to have the knowledge. But when you wanted medicine from that person that possessed the medicine, you had to give gifts in exchange. This was before money was around. Our people had their own ways of transaction. I guess you call that a transaction. You give away in exchange to buy the medicine. So you could use a gun, if you had a good gun, clothes or something of value. It could be snowshoes or moccasins that were used to purchase the medicine" (elder Matthew Strang, interview, Aug. 19, 2009, translated by Paddy Peters).

Medicinal plants and their associated knowledge held, and continue to hold, certain cultural and economic value to community members. An important principle in terms of exchange, or a transaction, is that reciprocity and a means to ensure reciprocity was, and is, a required procedure to show respect and to ensure the efficacy of the knowledge, or the objects exchanged.

\section{Coproducing knowledge with other stakeholders}

Elders taught us that coproducing knowledge about NTFPs requires respect for Anishinaabe institutions and processes. Within an Anishinaabe framework, there should be knowledgeable and authoritative individuals guiding knowledge coproduction processes. Because Anishinaabe protocols were gifted by the Creator to govern the access and use of knowledge and products, the elders should be in charge of guarding them. When asked about NTFP development, elder Sam Quill explained how traditions and skilled elders need to be part of the process to ensure the medicines work:

"The main topic is for the medicine to work (cheeauhnookeemuhkuhg). Individuals did not just go and harvest the medicine. It would have to be someone that was gifted to do that. There was a reason why they followed that traditional process. It was a way of having the medicinal plants work as medicine. Cheeauhnookeemuhkuhg oohmushkeekeem means observing that the medicine would work. The other thing is that the elders (Keecheeyuhneesheenuhbay) were given a sign for the medicine to work. They were given certain gifts. That is the only way that these medicines would work" (interview, Aug. 19, 2009).

Seeking out knowledgeable individuals is important for the correct development of NTFPs. Because of the personal, and even secretive, nature of special Anishinaabe knowledge and innovation methods, these practices may tacitly persist, or conversely, could re-emerge, triggered by new institutional context. The late-elder Oliver Hill emphasized the importance of the WFI, and the potential development of NTFPs, in revaluing and recultivating Pikangikum's knowledge tradition.

"I am deeply, deeply regretful. So we have to go back and retain this knowledge. [We have to] cheekeewayyuhng (to go back home) and nuhseekuhmuhng (to go and retrieve it)" (interview, Aug. 19, 2009, translated by Paddy Peters).

In the context of coproducing knowledge for designing NTFPs, elders and leaders emphasized the need to develop a positive working relationship based on collaborative decisionmaking. The late-elder Norman Quill explained that:

"There needs to be a collaboration of knowledges to find out. There has to be a working relationship too, because our people are interested in this working relationship. They [nonAboriginals] don't have knowledge of how to cure all aliments. But sometimes our people may hold that knowledge that the Whiteman is looking for. For instance, that diarrhea medicine that he talks about, if it works for our people then there should be research in that area using Whiteman's knowledge" (interview, Oct. 4, 2009, translated by Paddy Peters).

Pikangikum elders spoke about more than just the inclusion of Anishinaabe knowledge in scientific research. Elders want to have collaborative or joint research, which implies shared decision-making regarding research design, objectives, and outputs, such as intellectual property, NTFPs, and/or research publications. Collaborative and joint research would require committed, long-term partnerships with the Pikangikum community, the WFMC, and the WFESG.

\section{DISCUSSION}

Many discussions regarding environmental change have focused on adaptations. Adaptations may be specific technologies, practices, or institutions that arise in response to previous perturbations (abiotic, biotic, or climatic) at various levels of social organization (household, community, regions, countries) (Smit and Wandel 2006). Some of this work has recognized that it is necessary to understand the "economic-social-political" factors that enable or constrain adaptive capacity (Smit and Wandel 2006:289). Our case study regarding the Whitefeather Forest Initiative, and the specific discussion regarding NTFPs, emphasizes that indigenous cultural adaptation is occurring in the present, and in this case is enabled by economic, social, and political relations. While some scholars might think of this process as decolonization, or self-determination (Bryan 2012), Pikangikum has called this process "revival" or "being in the driver's seat" in making decisions for themselves about their future. While perhaps not yet central to discussions about environmental change, Pikangikum has insisted that institutions that guide the coproduction of knowledge are central to creating capacity for the strategic and intentional 
Table 2. History of knowledge coproduction processes and outcomes in Pikangikum First Nation.

\begin{tabular}{lll}
\hline \hline Time period & Nature of knowledge & Nature of institutions \\
\hline 1990s to 2006 & $\begin{array}{l}\text { Coproduction of knowledge and values in } \\
\text { community-based and provincial planning }\end{array}$ & $\begin{array}{l}\text { Development of the Whitefeather Forest Management } \\
\text { Corporation and Steering Group } \\
\text { Development of a working relationship with the } \\
\end{array}$ \\
& $\begin{array}{l}\text { Ministry of Natural Resources } \\
\text { Production of "Keeping the Land" }\end{array}$
\end{tabular}

2004 to present $\quad$ Coproduction of knowledge in the form of dissertations, theses, and publications Coproduction of knowledge in the form of the Cultural Landscape Atlas

2006 to present

Future

\begin{abstract}
Use of knowledge coproduced through the Whitefeather Forest Research Cooperative Coproduction of knowledge and values in community-based and provincial planning
\end{abstract}

Potential coproduction of knowledge, intellectual property, and novel nontimber forest products
Development of the Whitefeather Forest Research Cooperative and collaboration on various research projects

Development of the Pimachiowin Aki Corporation and UNESCO World Heritage Site nomination application

Development of forestry license application and commercial forestry planning in concert with the Ontario Ministry of Natural Resources

Potential development of partnerships with partners interested in developing commercial nontimber forest products response to environmental perturbations. Our case study on NTFPs considers the continuity between plant harvesting customs and the creation of new institutions to guide the coproduction of knowledge for NTFPs as part of the revival of an indigenous economy. Table 2 provides details on some of the knowledge and institutions as well as the broader outcomes that have been developed by the community through this process.

All Anishinaabe knowledge is meant for the benefit, survival, and well-being of the Anishinaabeg. Coproducing knowledge in response to environmental change requires community control, meaningful collaboration and partnerships, and significant benefit sharing with Pikangikum people. Knowledge sharing for the purposes of knowledge coproduction also implies the adherence to certain Anishinaabe institutions, such as monetary payment, exchange of valuables, or apprenticeships, which give value, show respect, and maintain its sanctity and efficacy in new contexts. Knowledge sharing and "transactions" do not, however, mean that knowledge would be owned or privatized.

The pivotal issue for coproducing knowledge is to involve Anishinaabe individuals who are seen to be culturally competent in producing environmental knowledge. Elders expressed interest in exchanging knowledge of the environment; however, they also stressed that they would have to be involved in creating the process by which the coproduction of knowledge would occur. Building adaptive capacity in response to environmental change can be enhanced by the coproduction of knowledge but requires the institutions that validate individual adaptations before they are accepted collectively.

Because of their experience on the land, Pikangikum's contemporary elders and experts guide leaders in processes of land use planning, development, and management of the Whitefeather Forest. Pikangikum elders explained how their knowledge continues to come from the Creator to support the WFI. In fact, novel institutions, such as the WFMC and WFESG, are the centers of community-based planning and decision-making. Recognizing the guidance of elders and the input of knowledge experts creates the conditions for collective cultural adaptation.

Given their specialized training in everyday life, Anishinaabe people are taught to observe, listen to, and respect those considered to be authoritative in a particular domain of knowledge. But, people choose, and are not obligated, to follow pathways, old or new. Working with others to coproduce environmental knowledge requires individuals to forge new ways of working with other non-Anishinaabe knowledgeable people who bring new sets of knowledge and skills to the table. Such processes of knowledge coproduction are in themselves intentional and proactive adaptations to a changing environment.

Elders are engaged in creating collective mechanisms that enable the coproduction of knowledge between the scientificbased knowledge of the Wemtigoshi ("Whiteman") and Anishinaabe knowledge. This shift in knowledge innovation, however, does not imply that Anishinaabe methods of 
knowledge innovation have permanently drifted into the past. Based on Pikangikum elders' guidance and advice, Anishinaabe institutions and values are continuing through a new collective mechanism, the Whitefeather Forest Management Corporation and Steering Group, as well as broader partnerships and knowledge coproduction institutions that involve Pikangikum, universities, and government departments. As such, the coproduction of knowledge and innovation for development and research, such as the NTFP example we have provided, functions through cross-cultural, interdisciplinary, and collaborative partnerships that include Pikangikum elders, government planners, and university researchers.

Elders seek meaningful participation as project and research advisors in the development of knowledge, institutions, and technologies in response to previous colonial relations with the state and changing global markets. As advisors, elders wish to share important Anishinaabe teachings and knowledge based on biology, ecology, cosmology, and morality; these are teachings that are seldom used in research and development projects. Our work with Pikangikum elders shows that there is a need to consider more than just knowledge about environmental change. In collaborative partnerships, researchers should also ask how knowledge is organized and produced across generations as well as how knowledge might be produced with others to generate creative responses to change.

Collaborative research conducted elsewhere has equally demonstrated how "...local communities, in a network of supportive partnerships, draw knowledge for [sic] others, combine it with their own knowledge and then innovate in their local practices" (Torri and LaPlante 2009:2). In this way, coproduction of knowledge can enhance adaptive capacity; it can bring new ideas and technologies from others to a community and it can provide checks and balances to ensure new ideas are acceptable to community members in terms of customary institutions and values (Davidson-Hunt and O'Flaherty 2007, Geniusz 2009). We would suggest that there has been an under emphasis in understanding indigenous peoples' creative response, and the institutional arrangements they have devised, to deal with changes in economic and political systems.

\section{CONCLUSION}

First Nations in Canada are responding to environmental change through relations established with stakeholders at multiple levels (Anderson 1997, Berkes and Davidson-Hunt 2007). These external relationships present individuals with a new range of technologies, values, and institutions that can become part of their response to environmental change. We advocate for more attention to the institutions that can allow for coproduction of knowledge to support First Nations as they respond to the legacies of change instigated by colonial governments and changing global markets.
In the case of Pikangikum, community members have established several successful partnerships through a collective organization they set up to mediate relationships among the individuals of the community, the First Nation, and government agencies/ministries (i.e., PFN and OMNR 2006) and universities (i.e., WFRC 2004). These partnerships have become loci of new institutional arrangements to respond to change rooted in custom and the values of Pikangikum people. It is through these new collaborative relationships that the elders envision generating new knowledge, understandings, and increased self-determination as they continue to confront a changing environment.

Responses to this article can be read online at: http://www.ecologyandsociety.org/issues/responses. $\mathrm{php} / 6001$

\section{Acknowledgments:}

We would like to thank Pikangikum First Nation, the Whitefeather Forest Management Corporation, and the Elders Steering Group for their support and participation in the research project Finding the Balance in the Bioeconomy: New Partnerships between Indigenous Socioeconomic Enterprises, Research Institutions and Corporations (PI: Dr. Robert Anderson, University of Regina). We would also like to recognize Mr. Paddy Peters who reviewed the article on behalf of the Whitefeather Forest Management Corp. as well as two anonymous reviewers. We also acknowledge the financial support of the University of Manitoba Faculty of Graduate Studies and the Social Sciences and Humanities Research Council of Canada. Finally, we would like to thank Erik Gómez-Baggethun, Victoria Reyes-García, and Esteve Corbera for inviting us to participate in their session, "Traditional ecological knowledge and resilience in the context of global environmental change," at the 2012 International Society of Ethnobiology Congress in Montpellier, France. We also thank the anonymous reviewers of the article who helped us clarify the focus of the paper.

\section{LITERATURE CITED}

Anderson, R. B. 1997. Corporate/indigenous partnerships in economic development: the First Nations in Canada. World Development 25(9):1483-1503. http://dx.doi.org/10.1016/ S0305-750X(97)00050-8

Armitage, D., F. Berkes, A. Dale, J. E. Kocho-Schellenberg, and E. Patton. 2011. Co-management and the co-production of knowledge: learning to adapt in Canada's Arctic. Global Environmental Change 21:995-1004. http://dx.doi.org/10.1016/ j.gloenvcha.2011.04.006 
Berkes, F. 2008. Sacred ecology. Routledge, New York, USA.

Berkes, F., J. Coldingm, and C. Folke, editors. 2003. Navigating social-ecological systems: building resilience for complexity and change. Cambridge University Press, Cambridge, UK. http://dx.doi.org/10.1017/CBO9780511541957

Berkes, F., and I. J. Davidson-Hunt. 2007. Communities and social enterprises in the age of globalization. Journal of Enterprising Communities: People and Places in the Global Economy 1(3):209-221. http://dx.doi.org/10.1108/17506200710779521

Berkes, F., and I. J. Davidson-Hunt. 2009. Innovating through commons use: community-based enterprises. International Journal of the Commons 4(1):1-6.

Bernard, H. R. 2006. Research methods in anthropology: qualitative and quantitative approaches. Altamira Press, Los Angeles, California, USA.

Breivik, E., and M. Supphellen. 2003. Elicitation of product attributes in an evaluation context: a comparison of three elicitation techniques. Journal of Economic Psychology 24:77-98. http://dx.doi.org/10.1016/S0167-4870(02)00156-3

Bryan, J. 2012. Rethinking territory: social justice and neoliberalism in Latin America's territorial turn. Geography Compass 6(4):215-226. http://dx.doi.org/10.1111/

j.1749-8198.2012.00480.x

Davidson-Hunt, I. J. 2006. Adaptive learning networks: developing resource management knowledge through social learning forums. Human Ecology 34(4):593-614. http://dx. doi.org/10.1007/s10745-006-9009-1

Davidson-Hunt, I. J., and F. Berkes. 2003. Learning as you journey: Anishinaabe perception of social-ecological environments and adaptive learning. Conservation Ecology 8 (1):5. [online] URL: http://www.consecol.org/vol8/iss1/art5/

Davidson-Hunt, I. J., and R. M. O'Flaherty. 2007. Researchers, indigenous peoples, and place-based learning communities. Society \& Natural Resources 20:291-305. http://dx.doi.org/10.1080/08941920601161312

Davidson-Hunt, I. J., and K. L. Turner, editors. 2012. Guest editorial. Indigenous communities, the bioeconomy and natural resource development. Journal of Enterprising Communities: People and Places in the Global Economy 6 (3):188-193.

De Leon, J. P., and J. H. Cohen. 2005. Object and walking probes in ethnographic interviewing. Field Methods 17 (2):200-204. http://dx.doi.org/10.1177/1525822X05274733

Deutsch, N., and I. J. Davidson-Hunt. 2010. Pikangikum family hunting areas and traplines: customary lands and Aboriginal land use planning in Ontario's Far North. Pages 149-170 in M. G. Stevenson and D. C. Natcher, editors.
Planning co-existence: Aboriginal issues in forest and land use planning. CCI Press and SFM Network, Edmonton, Alberta, Canada.

Ellen, R. 2007. Modern crises and traditional strategies: local ecological knowledge in island Southeast Asia. Studies in Environmental Anthropology and Ethnobiology, Vol. 6. Berghahn, Oxford UK.

Geniusz, W. M. 2009. Our knowledge is not primitive: decolonizing botanical Anishinaabe teachings. Syracuse University Press, Syracuse, New York, USA.

Hallowell, A. I. 1992. The Ojibwa of Berens River, Manitoba: ethnography into history. Case Studies in Cultural Anthropology. Harcourt Brace College Publishers, Toronto, Ontario, Canada.

Houde, N. 2007. The six faces of traditional ecological knowledge: challenges and opportunities for Canadian comanagement arrangements. Ecology and Society 12(2):34. [online] URL: http://www.ecologyandsociety.org/vol12/iss2/ art34/

Ingold, T. 2000. The perception of the environment: essays on livelihood, dwelling and skill. Routledge Press, London, UK.

Latour, B. 2005. Reassembling the social: an introduction to actor-network theory. Oxford University Press, Oxford, UK.

Mamow Sha-way-gi-kay-win. 2009. Pikangikum First Nation Searching Together Report. North South Partnership for Children and the Pikangikum Community Members: Participatory Assessment of Pikangikum.

Miller, A. M., I. J. Davidson-Hunt, and P. Peters. 2010. Talking about fire: Pikangikum First Nation elders guiding fire management. Canadian Journal of Forest Research 40:2290-2301. http://dx.doi.org/10.1139/X10-177

Nikisher, H. 2008. History and action in a resource planning relationship: Pikangikum's Whitefeather Forest Management Corporation and the Red Lake Ontario Ministry of Natural Resources. University of Manitoba, Winnipeg, Manitoba, Canada.

Pengelly, R. D. 2011. Developing and commercializing nontimber forest products: an Anishinaabe perspective from Pikangikum First Nation, Northwestern Ontario. Thesis. University of Manitoba, Winnipeg, Manitoba, Canada.

Pengelly, R. D., and I. J. Davidson-Hunt. 2012. Partnerships towards NTFP development: perspectives from Pikangikum First Nation. Journal of Enterprising Communities: People and Places in the Global Economy 6(3):230-250. http://dx. doi.org/10.1108/17506201211258405

Pikangikum First Nation and Ontario Ministry of Natural Resources (PFN and OMNR). 2006. Keeping the land [Cheekahnahwaydahmunk Keetahkeemeenahn]. A land use 
strategy for the Whitefeather Forest and adjacent areas. [online] URL: http://www.whitefeatherforest.com/wp-content/ uploads/2008/08/land-use-strategy.pdf

Sayre, S. 2006. Using video-elicitation to research sensitive topics: understanding the purchase process following natural disaster. Chapter 17 in R. W. Belk, editor. Handbook of qualitative research methods in marketing. Edward Elgar, Northampton, Massachusetts, USA. http://dx.doi. org $/ 10.4337 / 9781847204127.00025$

Smit, B., and J. Wandel. 2006. Adaptation, adaptive capacity and vulnerability. Global Environmental Change 16:282-292. http://dx.doi.org/10.1016/j.gloenvcha.2006.03.008

Tongco, M. D. C. 2007. Purposive sampling as a tool for informant selection. Ethnobotany Research and Applications 5:147-158.

Torri, M. C., and J. LaPlante. 2009. Enhancing innovation between scientific and indigenous knowledge: pioneer NGOs in India. Journal of Ethnobiology and Ethnomedicine 5:1-18. http://dx.doi.org/10.1186/1746-4269-5-29

Turner, N. J., I. J. Davidson-Hunt, and M. O'Flaherty. 2003. Living on the edge: ecological and cultural edges as sources of diversity for social-ecological resilience. Human Ecology 31:439-461. http://dx.doi.org/10.1023/A:1025023906459

Whitefeather Forest Research Co-operative (WFRC). 2004. Letter of Agreement. [online] URL: http://www. whitefeatherforest.com/wp-content/uploads/2008/06/wfrc-cooperativeagreement.pdf

${ }^{[1]}$ We use the term "Anishinaabe" as an adjective, and "Anishinaabeg" as a noun, which is the term our community research collaborators use to refer to themselves as a cultural group. 